\title{
Seroprevalence of Hepatitis B Infection among Pregnant Women at a Tertiary Care Hospital
}

\author{
B. Apoorva ${ }^{1}$, Mukesh Manjhi ${ }^{2}$, Sneha Mohan ${ }^{1 *}$ and Dalip K. Kakru ${ }^{1}$ \\ ${ }^{1}$ Department of Microbiology, School of Medical Sciences and Research, \\ Sharda University, U.P., India \\ ${ }^{2}$ Department of Dermatology, Hamdard Institute of Medical Sciences and \\ Research and HAH Hospital, Delhi, India \\ *Corresponding author
}

\section{A B S T R A C T}

\begin{tabular}{|l|}
\hline Ke y w o r d s \\
$\begin{array}{l}\text { Hepatitis B surface } \\
\text { antigen, Pregnant } \\
\text { women, } \\
\text { Seroprevalence }\end{array}$ \\
\hline Article Info \\
\hline $\begin{array}{l}\text { Accepted: } \\
\text { 17 August } 2020 \\
\text { Available Online: } \\
\text { 10 September } 2020\end{array}$ \\
\hline
\end{tabular}

Hepatitis B surface antigen is the first seromarker detected in the serum for active Hepatitis B infection. This is important to detect in pregnant women because if it goes undetected it can be harmful for both the mother and the foetus. In India prevalence rate of vertical transmission of HBV infection is also very high. To determine the seroprevalence of HBsAg among the pregnant women Study was conducted in the Serology Laboratory, Department of Microbiology, Sharda Hospital. It is a cross-sectional study. Qualitative detection of HBsAg was done from the patient's serum sample using the rapid test kit method, which yielded results within 20 minutes. Statistical analysis used: Nil. A total of 435 pregnant females were included in the study, out of which 12 were seropositive for HBsAg. Therefore, the prevalence rate was found to be $2.64 \%$ in the present study. Also, maximum positive cases were in the age group 20-25 years (75\%). As vertical transmission is responsible for majority of HBsAg infections in our country it is therefore important if we screen all pregnant females irrespective of their risk factors and give combined immunization and immunoprophylaxis to the high-risk babies born to the seropositive mothers. This will help in reducing the prevalence rate of the HBV infection in India.

\section{Introduction}

Hepatitis B infection is prevalent worldwide but it is more pronounced in Asia and Africa. Prevalence rate of HBV (Hepatitis B Virus) infection in pregnant women worldwide accounts for $0.5-1.5 \%$ whereas in India the rate is much higher $0.2-7.7 \%{ }^{[1]}$ Hepatitis $B$ infection leads to a wide range of clinical presentations from asymptomatic carrier state to acute self-limiting infections or fulminating hepatic failure, chronic hepatitis with progression to cirrhosis and hepatocellular carcinoma. The first seromarker which indicate active $\mathrm{HBV}$ infection is the hepatitis B surface antigen ( $\mathrm{HBsAg})$ in serum. ${ }^{[2]}$

Women at reproductive age groups and pregnant females are the most high-risk groups. Pregnant women also have the risk of 
transmitting the infection to the foetus via vertical transmission which is an important route of transmission of $\mathrm{HBV}$ infection. ${ }^{[3]}$ Several studies both worldwide and in our country recommends that pregnant females should be screened for HBV infection prevents the growing foetus and the neonate from getting chronically ill by the infection. ${ }^{[2]}$

Therefore, this study is done to determine the seroprevalence of HBsAg among pregnant individuals.

\section{Materials and Methods}

This study was conducted in the Department of Microbiology, Sharda Hospital. This is a hospital cross-sectional study including 435 pregnant women who attended the labour ward during the period of September 2019 to February 2020.

Blood samples were obtained by vein puncture, and serum was separated. Serum sample were tested for HBV infection using rapid card test for $\mathrm{HBsAg}$ detection and the results were obtained.

\section{Results and Discussion}

A total of 453 patients in the age group 20-30 years attended the Labour Ward during the study period were included in the study. Among the total subjects, 12 females were found to be seropositive for HBsAg. Hence, the prevalence rate was found to be $2.64 \%$ in the present study.

\begin{tabular}{|c|c|c|c|}
\hline $\begin{array}{c}\text { Age in } \\
\text { years }\end{array}$ & $\begin{array}{c}\text { Total } \\
\text { subjects }\end{array}$ & $\begin{array}{c}\text { No. of } \\
\text { positive } \\
\text { subjects }\end{array}$ & $\begin{array}{c}\text { \% } \\
\text { prevalence } \\
\text { based on } \\
\text { age group }\end{array}$ \\
\hline $\mathbf{2 0 - 2 5}$ & 302 & 9 & 75 \\
\hline $\mathbf{2 6 - 3 0}$ & 151 & 3 & 25 \\
\hline
\end{tabular}

Higher prevalence rate $75 \%$ was found in the age group of 20-25 years followed by $25 \%$ among 26-30 years. No co-infection was reported in any of the patients admitted. All the females who tested seropositive for HBsAg were followed up to the delivery and the baby was administered with both hepatitis $B$ vaccine and specific immunoglobulin in the early neonatal period to prevent the vertical transmission of the virus.

Screening pregnant females during their first prenatal visit is an important instrument of disease detection, prompt diagnosis and intervention especially concerning a typically asymptomatic infection such as chronic HBV infection itself. [2] In this study, the seroprevalence rate of $\mathrm{HBsAg}$ among pregnant females were found to be $2.67 \%$ which was in accordance to the study done by Lodha et al., in their review article on hepatitis B epidemiology where they have suggested the prevalence rate in India as 1$2 \%$. ${ }^{[4]}$ Similarly, in a systematic review of prevalence of hepatitis B in India by Ashish Batham et al., found the point prevalence of $2-4 \%$ among the non-tribal population. ${ }^{[5]}$

There is a wide variation in the prevalence rate depending on the different regions of our country also. High prevalence rate of $9.5 \%$ was reported by Praksh et al., in North India [6] and comparative low prevalence rate of $0.9 \%$ was reported by Dwivedi and colleagues, ${ }^{[7]} 0.82 \%$ reported by Chaterjee et al., ${ }^{[8]} 1.1 \%$ reported by Pandy et al., ${ }^{[9]}$ and $1.11 \%$ reported by Sibia P et al., ${ }^{[10]}$

In our study the prevalence rate of Hepatitis B infection was higher among the age group 2025 years $(75 \%)$. Similar correlation was observed by Kolou M et al., where higher prevalence rate was seen among 20-29 years (26.33\%) [11] also, Pontius Bayo et al., reported higher prevalence among women aged 20 years $(20 \%) .^{[12]}$ However, Sathiyakala et al., found a higher prevalence rate among the age group 26-30 (46.1\%). ${ }^{\text {[2] }}$ 
Between $30-40 \%$ of all chronic HBV infection results from perinatal transmission. Therefore, universal prenatal screening for HBsAg substantially reduces perinatal transmission of $\mathrm{HBV}$ and the subsequent development of chronic HBV infection. ${ }^{[2]}$

There are limitations to this study also as only HBsAg was tested as marker for hepatitis B infection. If other markers were combined with HBsAg the study would have been more informative and reliable.

\section{References}

1. Mishra S, Purandare P, Thakur R, Agrawal S, Alwani M. Study on prevalance of hepatitis $\mathrm{B}$ in pregnant women and its effect on maternal and fetal outcome at tertiary care centre. Int $\mathrm{J}$ Reprod Contracept Obstet Gynecol., 2017; 6: 2238- 40.

2. Sathiyakala R, Ushadevi G, Karthika J. Int J Reprod Contracept Obstet Gynecol. 2017 Jan; 6(1): 249-251.

3. Schweitzer IL. Vertical transmission of hepatitis B surface antigen. Am J Med Sci. 1975; 270:287-91.

4. Lodha R, Jain Y, Anand K, Kabra SK, Pandav CS. Hepatitis B in India: A review of disease epidemiology. Indian Pediatrics. 2001; 38(4): 349-71.

5. Batham A, Narula D, Toteja T, Sreenivas V, Puliyel JM. Systematic review and meta-analysis of prevalence of hepatitis B in India. Indian Pediatrics. 2007: 44(9): 663-74
6. Prakash C, Sharma RS, Bhatia R, Verghese T, Datta KK. Prevalence of North India of hepatitis B carrier state amongst pregnant women. Southeast Asian J Trop Med Public Health. 1998; 29: 80-4

7. Dwivedi M, Misra SP. Seroprevalence of hepatitis B infection during pregnancy and risk of perinatal transmission. Indian $\mathrm{J}$ Gastroenterol. 2011; 30:66

8. Chatterjee S, Ravishankar K, Chaterjee R, Narang A, Kinikar A. Hepatitis B prevalence during pregnancy. Indian Pediatr. 2009;46: 1005-8

9. Pande C, Sarin SK, Patra S. Prevalence, risk factors and virological profile of chronic hepatitis $B$ virus infection in pregnant women in India. J Med Virol. 2011; 83: 962-7. 21.

10. Sibia P. Seroprevalence of Hepatitis B Infection among Pregnant Women in One of the Institute of Northern India. Journal of Clinical and Diagnostic Research. 2016; 10(8):QC08-9.

11. Kolou M, Katawa G, Salou M,GazoAkakpo KS, Dossim S, Kwarteng A et al., High Prevalence of Hepatitis B Virus Infection in the Age Range of 20-39 Years Old Individuals in Lome. Open Virol J. 2017; 11:1-7.

12. Bayo P, Ochola E. High Prevalence of hepatitis $\mathrm{B}$ virus infection among pregnant women attending antenatal care: a crosssectional study in two hospitals in Northern Uganda. BMJ Open. 2014; 4: e005889.

\section{How to cite this article:}

Apoorva, B., Mukesh Manjhi, Sneha Mohan and Dalip K. Kakru. 2020. Seroprevalence of Hepatitis B Infection among Pregnant Women at a Tertiary Care Hospital. Int.J.Curr.Microbiol.App.Sci. 9(09): 2164-2166. doi: https://doi.org/10.20546/ijcmas.2020.909.270 